\title{
The Difficult Art of Giving
}


This page intentionally left blank 


\title{
The Difficult Art of Giving
}

\author{
Patronage, Philanthropy, \\ and the American Literary Market
}

Francesca Sawaya

\author{
$\overline{\text { PENN }}$ \\ UNIVERSITY OF PENNSYLVANIA PRESS \\ PHILA DEL PHIA
}


A volume in the Haney Foundation Series, established in 1961 with the generous support of Dr. John Louis Haney

Copyright (C) 2014 University of Pennsylvania Press

All rights reserved.

Except for brief quotations used for purposes of review or scholarly citation, none of this book may be reproduced in any form by any means without written permission from the publisher.

\author{
Published by \\ University of Pennsylvania Press \\ Philadelphia, Pennsylvania 19104-4112 \\ www.upenn.edu/pennpress \\ Printed in the United States of America \\ on acid-free paper \\ $\begin{array}{llllllllll}10 & 9 & 8 & 7 & 6 & 5 & 4 & 3 & 2 & 1\end{array}$
}

A Cataloging-in-Publication record is available from the Library of Congress

ISBN 978-0-8122-4630-8 